\title{
Consumption Patterns and Cosmetic Consumer Brand Loyalty
}

\author{
Anisa Rima Fadhilah* \\ Department of Psychology \\ Universitas Negeri Yogyakarta \\ Yogyakarta, Indonesia \\ anisarimaf3@gmail.com*
}

\author{
Yulia Ayriza \\ Department of Psychology \\ Universitas Negeri Yogyakarta \\ Yogyakarta, Indonesia \\ yulia_ayriza@uny.ac.id
}

\begin{abstract}
This study aims to describe the tendency of consumption patterns and brand loyalty of the cosmetic consumers in Yogyakarta. This research is a preliminary study for further research which aims to find out a dynamic model of cosmetic consumer loyalty. This research applied quantitative approach with survey method. The research involves 50 female cosmetic consumers that fulfills the inclusion criteria: a) respondents must be active consumers of cosmetic products (indicated by cosmetic purchasing behaviors at least once in the past six months), b) living in Yogyakarta, c) aged between 16 up to 30 years. The data were collected by distributing online questionnaires with open-ended questions and were analyzed using quantitative descriptive technique. The results showed that: (1) face powder and lipstick are the most-used and mostpurchased cosmetic products by consumers, (2) 50 percent of cosmetic consumers intended to keep using their current brand, 34 percent of them switched brands, and 4 percent others used multi-brands, and (3) 88 percent of face powder and lipstick consumers switched brands more than twice because of curiosity, variety-seeking, looking for the best value product, incompatible cosmetic formula on their facial skin, poor quality, poor performance of previous brands, and the lower price of products from other competitors.
\end{abstract}

Keywords-consumption pattern, brand loyalty, cosmetic consumers, consumer behavior

\section{INTRODUCTION}

Cosmetic market and consumer behavior are dynamic. Therefore, researchers in the field of consumer behavior are trying to find out the actual condition, the novelty and the actual phenomena in the current cosmetic consumer behavior. Two topics that related to cosmetic consumer behavior that are often studied and received great concern are consumption patterns $[1,2,3,4]$ and brand loyalty $[5,6$, $7,8]$. Consumption patterns in general can be defined as how consumers spend their money by buying a number of products and services to fulfill their needs and satisfaction. Meanwhile, brand loyalty can be defined as a positive attitude towards the brand that indicated by regular purchases of the brand and commitment to keep consuming it in the future [9].

The study of consumption patterns and brand loyalty has become a major concern in recent years. It is shown by various surveys that pay great attention to this topic in various regions, including Indonesia $[10,11,12,13,14,15$, 16]. These phenomena-the various survey institutions that pay attention to the research of consumption patterns and brand loyalty of cosmetic consumers-is inseparable from the increased growth of national cosmetic industry. It is known that the national cosmetic industry has grown by more than $20 \%$ or four times compared to the national economic growth [17]. This growth occurs due to the rising demand for cosmetic products of the Indonesian consumers which have made cosmetics as the one of their important needs.

The company certainly want their consumers to be loyal and keep consuming their brand, because the loyal consumers can give several benefits to the company such as reaching higher sales, reducing the company's costs for marketing efforts, and achieving efficiency [18]. However, the phenomenon shows the opposite. Cosmetic consumer loyalty is not static but dynamic in which indicated by a decrease in brand loyalty of cosmetic consumers.

The results of a survey conducted by Mars Indonesia in 2009 showed that $76.4 \%$ of cosmetic consumer are loyal for face powder product and $72.6 \%$ loyal for lipstick product [10]. However, it was found through a survey by Nielsen in 2013, that cosmetic consumers showed a dynamic behavior. The survey by Nielsen revealed that the percentage of consumers using one brand decreased from $49.2 \%$ to $45.4 \%$ and cosmetic consumers that using two brands increased from $24.9 \%$ in 2012 to $31,9 \%$ in 2013 . The percentage of cosmetic consumers who bought more than two brands increased from $27.1 \%$ to $30.2 \%$, while consumers who bought more than three brands increased from $12.4 \%$ to $15.9 \%$ [15].

The decrease in the number of loyal consumers can have impacts on the lower sales levels, higher costs for marketing efforts to attract and maintain consumer loyalty to the company's brand. This makes the company's efficiency decreased and the sustainability of the company is threatened.

This research is a preliminary study for further research that aims to find out the dynamic model of brand loyalty in cosmetic consumers. This study will become the basis for the further research in exploring how the dynamic model of brand loyalty in cosmetic consumers. The study of consumption patterns can provide benefits for companies in understanding what kind of products that consumers are interested in in the market today and how their potential in the market. Meanwhile, a study of how the condition of consumer brand loyalty can provide an overview of whether consumers currently tend to be loyal to one or more brands, whether consumers have strong or weak loyalties 
characterized by intentions or actual behavior of brand switching. This can be a tool for companies to ensure the sustainability of their business.

Based on the previous description, it is concluded that consumption patterns and brand loyalty behavior of cosmetic consumers has changed over time or dynamic. Thus, based on the background of the problem that has been described, the problem statements were: (1) what is the most-used and most-purchased cosmetic product by consumers? (2) how is the cosmetic consumer loyalty to face powder and lipstick products? This study is expected to help the cosmetic companies in managing their brand sustainability and marketing strategies which are in accordance with the conditions of today's cosmetic consumer behavior.

\section{METHODS}

This study applied a quantitative approach with survey method with the reason that research objectives is to describe trends, behaviors, and opinions of the population by studying the sample of it [19].

This study involved fifty female cosmetic consumers, which were selected using purposive sampling technique. Inclusion criteria used in this research are (in which the criteria were they) respondents must be active consumers of cosmetic products (indicated by the last purchases at least once in the past 6 months), b) living in Yogyakarta, c) and aged between $16-30$ years.

The data were collected by distributing online questionnaires. It contained four open-ended questions, i.e. (1) what were the most-used cosmetic products by consumers?, (2) what were the most-purchased cosmetic products in the last 6 months?, (3) how many times the consumers switched cosmetic brands and what were the reasons of it, and (4) what was the consumers intention either to switch brands or to be loyal to their current cosmetic brands. The data were analyzed using descriptive statistics.

The research was conducted during September to November 2018. The steps of this research were: (1) Determining the criteria of the respondents for this study, (2) constructing the questionnaires with open-ended questions, (3) collecting data by distributing the online-questionnaires, (4) analyzing and interpreting the data, and (5) presenting the results on research report.

\section{RESULT AND DISCUSSION}

Result

Related to the consumption patterns of cosmetic consumers, the results showed that there were five categories of cosmetic products which are often used and purchased regularly by the consumers i.e., face powder, lipstick, moisturizer, BB cream, and sunscreen.

Table 1. The Mosr Used Cosmetic Products by Consumer Regurarly

\begin{tabular}{|c|l|c|c|}
\hline \multirow{2}{*}{ No. } & \multicolumn{3}{|c|}{ Most-Used Cosmetic Product by Consumers } \\
\cline { 2 - 4 } & Product Categories & Frequency & Percentage \\
\hline 1. & Face Powder & 36 & $72 \%$ \\
\hline 2. & Lipstick & 35 & $70 \%$ \\
\hline 3. & Moisturizer & 11 & $22 \%$ \\
\hline 4. & BB Cream & 8 & $16 \%$ \\
\hline 5. & Sunscreen & 7 & $14 \%$ \\
\hline
\end{tabular}

Based on table 1, there were $72 \%$ respondents stated that face powder was the cosmetic product which were often purchased regularly, followed by lipstick product $(70 \%)$, moisturizer product (22\%), BB cream (16\%), and sunscreen product (14\%). From these results, it can be concluded that face powder is the most purchased cosmetic product by consumers which they bought regularly.

Tabel 2. The Most Purchased in Past 6 Months

\begin{tabular}{|l|l|c|c|}
\hline \multirow{2}{*}{ No. } & \multicolumn{3}{|c|}{ Most-Used Cosmetic Product by Consumers } \\
\cline { 2 - 4 } & Product Categories & Frequency & Percentage \\
\hline 1. & Lipstick & 30 & $60 \%$ \\
\hline 2. & Face Powder & 7 & $14 \%$ \\
\hline 3. & Moisturizer & 6 & $12 \%$ \\
\hline 4. & Others & 7 & $14 \%$ \\
\hline 5. & Lipstick & 30 & $60 \%$ \\
\hline
\end{tabular}

Meanwhile, based on table 2, in the past 6 months, it was known that $60 \%$ respondents made the most frequent purchases in lipstick product, followed by face powder product $(14 \%)$, moisturizer $(2 \%)$, and the other $14 \%$ made purchases on the other cosmetic products which were not specified in this study. From these results above, it can be concluded that even face powder product is the mostpurchased cosmetic product by consumers regularly (showed in Table I), but lipstick is the most frequently purchased cosmetic product by consumers.

Table 3. Picture of Brand Switching

\begin{tabular}{|c|l|c|c|}
\hline \multirow{2}{*}{ No. } & \multicolumn{3}{|c|}{ Factors of Brand Switching } \\
\cline { 2 - 4 } & Brand Switching Motives & Frequency & Percentage \\
\hline 1. & $\begin{array}{l}\text { Curiosity, variety-seeking, need } \\
\text { for novelty }\end{array}$ & 16 & $32 \%$ \\
\hline 2. & $\begin{array}{l}\text { Looking for the best value } \\
\text { product/brand }\end{array}$ & 10 & $20 \%$ \\
\hline 3. & $\begin{array}{l}\text { Incompatible cosmetic formula } \\
\text { on consumer skin }\end{array}$ & 10 & $20 \%$ \\
\hline 4. & $\begin{array}{l}\text { Poor quality and poor } \\
\text { performance of previous brand }\end{array}$ & 5 & $10 \%$ \\
\hline 5. & $\begin{array}{l}\text { Lower price of competitors' } \\
\text { brand }\end{array}$ & 2 & $4 \%$ \\
\hline
\end{tabular}

Based on table 3, related to the cosmetic consumer brand loyalty, it was found that out of the fifty respondents, $88 \%$ stated that they had switched their lipstick and face powder brands more than twice. The main reason of brand switching in lipstick and face powder products is dominated by factors of curiosity, variety-seeking, and need for novelty (32\%), followed by factor of looking for the best value product (20\%) and the factor of incompatible cosmetic formula on their facial skin (20\%), and the factor of poor quality and poor product performance of previous brand (10\%). Finally, it was found that only $4 \%$ switched their face powder and lipstick brands because of the lower price of the products from other competitors.

Further, after switching brands, cosmetic consumers in lipstick and face powder products showed intention either to switch brands or to keep consuming the same brands. Based on Figure 1, it was $50 \%$ percent respondents intended to be loyal or keep consuming their current cosmetic brands, $34 \%$ would switch brands, the other $4 \%$ intended to use multibrand (more than one brand). Meanwhile, $12 \%$ respondents stated that they did not know whether to switch brands or to 
be loyal to their current brands. From these results, we can conclude that $34 \%$ cosmetic consumers still intended to switch their brand even they already switched their brands before.

\section{Discussion}

Based on the results of the study, it was found that face powder and lipstick products were the most-used and the most-purchased cosmetic category by consumers with a percentage of $72 \%$ in face powder products and $70 \%$ in lipstick products. This result was in line with three research findings as described below $[11,16,20]$.

The first survey conducted by MARS Indonesia in 2017 entitled "Studi Pemasaran Produk Kosmetik di Indonesia 2017" showed that the highest penetration of cosmetic products was in face powder and lipstick categories with sales value for face powder product at 84.6 and in lipstick product at $82.9[11]$. The result indicate that face powder and lipstick products were the best-selling cosmetic category on the market compared to the other cosmetic categories.

The second survey conducted by Navitasari, Gunawan, and Persada in 2018 on active cosmetic consumers in Surabaya showed that facial cosmetic products, including face powder $(37,41 \%)$ and lipstick $(55,8 \%)$ were the mostused cosmetic products [19]. The last study that conducted by Snapcart (2016) which involved cosmetic consumers with the ages of 25-34 years old as respondents in five biggest cities in Indonesia (Jakarta, Surabaya, Medan, Bandung, and Makassar). The result showed that face powder and lipstick products ranked in the second and third position in term of highest sales, while the first position was occupied by moisturizer product [16].

Thus, this study findings were in line with those three studies of which that face powder, lipstick and moisturizer products were the most-purchased cosmetic products. This strengthens the evidence that face powder, lipstick and moisturizer products are still the categories of cosmetic products that are most-used and most-purchased by consumers and have a great opportunity to grow in cosmetic market.

\section{Post-Purchase Behavior: Brand Switching and Multibrand Loyalty.}

Based on the results of the study, it is known that cosmetic consumers do not always use the same cosmetic brands, instead they switched brands especially in face powder and lipstick products with the reason of functional and psychological motives.

The functional motives that make consumers switched brands were looking for the best value product and the best product performance, incompatible cosmetic formula on consumers' skin, as well as poor quality and poor performance of the previous brand. Meanwhile, the psychological motives that make cosmetic consumers switched brands were curiosity, variety-seeking, and need for novelty. This result was also in line with a study conducted by Navitasari, Gunawan, and Persada in 2018, of which $38.90 \%$ cosmetic consumers in Surabaya were also found to performed brand switching when they felt incompatible with the previous brand [20].
Regarding variety-seeking behavior of cosmetic consumers in this study, the results was in line with a survey conducted by Corra in 2016 with 1000 female cosmetic consumers as the sample, 1/3 of them were found switched their lipstick brands overtime and only $6 \%$ of them had a preference to be loyal to previous lipstick brands, while the rest prefered to try new lipstick brands as an alternative of either to switch brands or be loyal to the previous ones [21].

The cosmetic consumers behavior such variety-seeking behavior that we found in this study can be explained by the optimum stimulation level theory. Consumers as individuals have exploratory behavior and drive to achieve comfort by seeking for new stimulation. This means that when consuming a brand, consumers have a sense of boredom, desire to try new things, or a need for sensing new stimulus over time to reach a state in which consumers feel comfortable with the exposure of the stimuli up to a certain level (Optimum Stimulation Level) [22]. This is what we predicted to be the reason of cosmetic consumer switching brands in face powder and lipstick products, i.e. varietyseeking behavior and intention to consume multiple brands (more than one brand).

Furthermore, related to the post-purchase behavior, it was found that consumers predominantly intended to be loyal to the current brands (50\%). Nevertheless, it was found that $34 \%$ consumers intended to switch brands and consume multiple brands (more than one brand). Post-purchase attitude of cosmetic consumers such as intention to switch brands and to consume multiple brands found in this study is contrary to the concept of loyalty which needs to be concerned by the companies of cosmetic products.

The results of this study provide insight that face powder and lipstick products are still the most-purchased cosmetics by consumers. Further, the cosmetic consumers were also found to switch brands more than twice, because of functional motives (looking for best value brands with the best quality and performance) and psychological motives (curiosity, variety-seeking and need for novelty).

\section{CONCLUSION}

Based on the results of this study, it can be concluded that face powder and lipstick categories are the most used and purchased cosmetic products. It is also known that lipstick products are the most-purchased cosmetic category in the past 6 months. Regarding cosmetic consumer brand loyalty behavior, $88 \%$ face powder and lipstick consumers switched brands more than twice due to the factors of curiosity and variety-seeking as a psychological motives and looking for the best value product, incompatible cosmetic formula on their facial skin, poor quality, poor performance of previous brand, and the lower price of competitors' product as a functional motives. Finally, it was found that $50 \%$ cosmetic consumers intended to be loyal to current cosmetic brands, whereas $34 \%$ intended to switch their brands, $4 \%$ intended to consume multi-brands, and the rest of $12 \%$ respondents were not certain of their choices of either to switch brands or be loyal to their previous ones. This finding provides a new knowledge that cosmetic consumers brand loyalty is a dynamic behavior which indicated by brand switching behavior overtime. 


\section{REFERENCES}

[1] TABS Group. (2014). Infographic-cosmetics buyers.Retrieved on October, $18^{\text {th }} 2018$ from: https://www.tabsanalytics.com/

[2] S. Mulyani, "Pola konsumsi non makanan mahasiswa Program Studi Pendidikan Ekonomi Fakultas Ekonomi Universitas Negeri Yogyakarta," Undergraduate Thesis.Program Studi Pendidikan Ekonomi.Universitas Negeri Yogyakarta, 2015

[3] N. Hanum, "Analisis pengaruh pendapatan terhadap perilaku konsumsi mahasiswa Universitas Samudra di Kota Langsa," Jurnal Samudra Ekonomika, vol.1 (2), pp.107-116, November 2017

[4] R. Husna, "Analisis perilaku konsumen muslim dan perilaku expenditure switching konsumen muslim terhadap konsumsi kosmetik berlabel halal," Undergraduate Thesis.Fakultas Ekonomika dan Bisnis.Universitas Diponegoro, 2016

[5] R.M.C. Nunes, "The dynamics of brand loyalty across a consumer's lifetime: An application to the Portuguese fashion market," Dissertation.NOVA School of Bussiness and Economics, 2014

[6] R.M. Joelle, "Brand loyalty in cosmetic products among women perception:Brand wardah," in International Conference on Education in the $21^{\text {th }}$ Century:Responding to Current Issues, Malang:Universitas Negeri Malang, 2017, pp.798-805

[7] S. Sanaji and T.A. Indarwati, "Dinamika loyalitas konsumen dalam pemilihan merek: Studi kasus pada pembelian ulang mobil," in Prosiding Seminar Nasional dan Call for Papers Manajemen Ekonomi Akuntansi (SENMEA), Kediri:Fakultas Ekonomi UNP Kediri, 2016, pp.52-59

[8] M.B. Darma, S. Effendi, and A.A. Juari, "Pengaruh citra merek dan kepuasan pelanggan terhadap loyalitas pelanggan kosmetik," Jurnal Riset Sains Manajemen, vol.2 (1), pp.1-8, February 2018

[9] A.S. Dick and K. Basu, "Customer loyalty:Toward an integrated conceptual framework," Journal of the Academy of Marketing Science, vol.22 (2), pp.99-113, March 1994

[10] MARS Indonesia.(2009).Tingkat loyalitas konsumen produk kosmetika.Retrieved on October, $18^{\text {th }} 2018$ from: http://www.marsnewsletter.wordpress.com/

[11] MARS Indonesia. (2017).Studi pemasaran kosmetik 2017.Retrieved on October, $12^{\text {nd }} 2018$ from: http://www.marsindonesia.com/
[12] Saviq, B. (2017).Menganalisis konsumsi kosmetik perempuan millenials Indonesia. Retrieved on October, $18^{\text {th }} 2018$ from: https://marketers.com/

[13] Euromonitor. (2014). Using brand loyalty to tailor product offerings in beauty and personal care. Retrieved on November, $1^{\text {st }} 2018$ from: https://blogeuromonitor.com/

[14] McDougall, A. (2015).Olders consumers are generally more brand loyal while millenials seek innovation. Retrieved on October, $18^{\text {th }}$ 2018 from: https://www.cosmeticsdesign-europe.com/

[15] Jakarta Post. (2013). Prospects for cosmetics industry are looking good. Retrieved on October, $18^{\text {th }} 2018$ from: https://www.thejakartapost.com

[16] Markeeters. (2017).Menganalisa konsumsi kosmetik perempuan milenial Indonesia. Retrieved on June, $20^{\text {th }} 2019$ from: https://marketeers.com/

[17] Kementerian Perindustrian Republik Indonesia. (2018). Industri kosmetik nasional tumbuh 20\%. Retrieved on October, $10^{\text {th }} 2018$ from: https://kemenperin.go.id/

[18] Giddens, N. (2010). Brand loyalty.Ag Decision Maker.Retrieved from:www.extension.iastate.edu/agdm

[19] J.W. Creswell, Research design:Pendekatan metode kualitatif, kuantitatif, dan campuran, $4^{\text {th }}$ ed., Ind Trans. Achmad Fawaid and Rianayati Kusmini Pancasari.Yogyakarta:Pustaka Pelajar, 2016, pp. 208

[20] N. Navitasari, J. Gunawan, dan S.F. Persada, "Analisis deskriptif pengguna kosmetik aktif di Surabaya," Jurnal Sains dan Seni Pomits, vol.7(1), pp.18-21, February 2018.

[21] Corra Research. (2016). Beauty product loyalty.Retrieved on October, $18^{\text {th }} 2018$ from:https://corra.com/

[22] H. Baumgartner and J.B.E.M. Steenkamp, "An investigation into the validity of raju scale of exploratory behavior tendencies," in Marketing Thought Around the World, vol. I, F. Bradley, Ed.EMAC: University College Dublin, 1991, pp.1-20 